Exceptional Children, Vol. 52, No. 4, pp. 347-352.

- 1986 The Council for Exceptional Children.

\title{
Appropriate Education and Rowley
}

\author{
H. RUTHERFORD TURNBULL, III
}

\begin{abstract}
The Education of the Handicapped Act requires state and local educational agencies to provide a free, appropriate public education to all children with disabilities. The meaning of "appropriate" was left quite open-ended by Congress, which predicated "appropriateness" on compliance with state standards and a child's IEP. The Supreme Court's first special education case, Board v. Rowley (1982), clarified the meaning of "appropriate" - as did the Court's later decision, Irving I.S.D. v. Tatro (1984)-but raised questions about just how far the EHA requires schools to go in educating a child. This article analyzes Rowley's meaning for "appropriate" education and justifies the rightness of that decision in terms of its impact on the education of the child and the integration of children who have disabilities with children who do not.
\end{abstract}

The legal requirement that children with disabilities be provided an appropriate education originated in Pennsylvania Association for Retarded Children (1971, 1972), Mills (1972), and other cases that laid the foundation for the Education for All Handicapped Children Act (P.L. 94-142), amending Part B of the Education of the Handicapped Act (EHA) (20 U.S.C. Secs., 1401-1461). In the Act, Congress found as a matter of fact that more than one half of all children with disabilities did not (as of 1975) receive an appropriate education. To remedy this situation, it required state and local educational agencies funded under Part B of the EHA to provide a free, appropriate public education, but it did not adequately define "appropriate." Thus, just as case law required appropriateness in the first place, so case law was required to interpret Congress' intention on "appropriateness." Board

H. RUTHERFORD TURNBULL, III, is Professor of Special Education and Law, The University of Kansas, Lawrence. v. Rowley (1982), the Supreme Court's first special education case, defined "appropriate" in the context of the EHA, building on Congress' own definitions and the principal means of appropriateness-the individualized education program-and in the context of Section 504 of the Rehabilitation Act Amendments of 1973, prohibiting discrimination in federally aided education against otherwise qualified handicapped people.

\section{DEFINITIONS OF APPROPRIATE EDUCATION}

There are few statutory definitions of "appropriate education" in the EHA. One of them derives from an understanding of the EHA as a whole. That definition seeks to define appropriate education by a process that looks first to the child and second to the means by which an appropriate education is to be provided. It is child-centered and processoriented, not system-centered or result-oriented; it takes account of educational "inputs," not educational "outputs." 
For example, assume a 9-year-old child is moderately mentally retarded and school personnel (and the parents) are concerned about what kind of education and what kind of placement is appropriate. How do they answer this question? They do it by (1) enrolling the child; (2)making a nondiscriminatory evaluation; (3) developing an individualized education program (IEP); (4) attempting to place the child in the least restrictive appropriate program; (5) seeing that, throughout this process, the parents have access to the child's school records; and (6) calling a due process hearing, if the parents or school personnel wish to protest the placement or any other action related to the child's right to a free appropriate education. The Act's technique for defining "appropriate," then, is to require that a process be followed, in the belief that a fair process will produce an acceptable result-an appropriate education.

The regulations implementing the EHA also define free appropriate education for special education and related services in terms of state education agency standards and conformity with IEPs. Specifically, the regulations define free appropriate public education as one that (1) is provided at public expense, under public direction and supervision, without charge; (2) meets the standards of the state education agency; (3) includes preschool, elementary, and secondary school education; and (4) is provided in conformity with IEP requirements of the EHA and its regulations.

The regulations under Section 504 provide a third way to define appropriate education. They require schools to furnish children with special education and related aids and services designed to meet their educational needs as adequately as the needs of nonhandicapped children are met (an equivalency definition). The program must be based on least restrictive placement principles and include a full and individual preplacement evaluation, a nondiscriminatory evaluation, annual reevaluation of special education placement, and procedural due process. Implementing an IEP is one way to provide an appropriate education, but Section 504 regulations do not require an IEP. Like the EHA, however, Section 504 addresses the requirement of appropriate or individualized education by requiring that schools follow a process. Unlike the language of the EHA and its regulations, Section 504 requires equiv- alency in education between handicapped and nonhandicapped students.

Given the EHA's process of definition of appropriate education, the state standards and IEP definition in the EHA regulations, the comparability definition of the Section 504 regulations, and the further requirement in both that an appropriate education must be in the least restrictive environment (LRE), it was clear at the outset that courts would be called on to further clarify appropriate education and its relationship to the least restrictive environment requirement. For the purpose of explaining the courts' interpretations here, it is not necessary to consider the LRE cases and their impact on the meaning of appropriate education. Here, it will be useful to consider only how courts have interpreted the other definitions of appropriate education, bearing in mind the LRE rule.

\section{HISTORY OF ROWLEY}

The Rowley decision (Board v. Rowley, 1982) has become the touchstone for all subsequent appropriate education cases. More than that, it also incorporated much of the reasoning and results of prior appropriate education cases decided by other courts and, as such, has national implications. Its history and principles, therefore, are worthy of close examination.

In Rowley, a federal district court and the Second Circuit Court of Appeals both held that a school district must provide a sign language interpreter in the classroom as part of a deaf child's individualized education program in order to comply with requirements of the EHA. The courts found that, as a matter of law, a child's education must be comparable to that given nonhandicapped children, not the best education available. Under the facts in this case, they found that comparability would not be achieved without an interpreter.

The court of appeals noted that the decision was restricted to the facts of this case (the child's parents were also deaf, and evidence at the trial showed that, without an interpreter, only $59 \%$ of what transpired in the classroom was accessible to the child). One judge filed a lengthy dissent, citing the extensive efforts the school district had already made on behalf of the child. 
The Supreme Court reversed the court of appeals, holding that the EHA does not require the school to provide the student with an interpreter in order to comply with the mandate of an appropriate education. The Court emphasized the EHA legislative history. As the Court read that history, it concluded that Congress had not intended that the schools try to develop to their maximum children who are disabled. Instead, the EHA's purpose was basically to open the schools' doors to them, granting them access to educational opportunities. Accordingly, congressional intent is satisfied when the school provides the student with a reasonable opportunity to learn.

Because the student in this case had progressed from grade to grade without an interpreter's help, there was evidence of the school's compliance with the "open doors" intent of Congress. In this aspect of the case, the Court, relying to a great extent on EHA legislative history, essentially adopted the comparability standard (the Section 504 approach). If the open doors rule were not adopted (i.e., if comparable treatment were not required), the "maximum development" purpose would be appropriate (i.e., the EHA would have been read to require the child's maximum development and, hence, an interpreter). Because the interpreter was not required, the EHA requires only comparability.

The Court also stressed the importance of the law's procedures for defining and providing an appropriate education. Specifically, it noted that all of the professionals involved in developing the child's IEP were of the opinion that the child could be educated appropriately without an interpreter. In addition, it pointed out the many ways in which the law allows the child's parents to be involved in the IEP process and otherwise.

\section{IMPACT OF ROWLEY}

The Rowley decision undoubtedly is quite limited by its facts as precedent for other cases. For example, because the student was in a regular class, it is doubtful that the Court's emphasis on grade-to-grade promotion would apply to children with disabilities who do not or cannot progress from grade to grade in the mainstream or whose progress cannot be measured by that standard. It also is doubtful whether the decision would apply to children who require related services in order to be educated in the mainstream, such as the spina bifida children in the Tatro case (Irving I.S.D. v. Tatro, 1984). The Supreme Court's own Tatro decision confirmed that suspicion.

But Rowley's implications-the principle of comparability and the Court's reliance on professionalism and process-is great. Some of the cases summarized in the following paragraphs reflect Rowley's impact.

\section{Principle of Comparability}

The first of Rowley's principles is that the EHA was designed only to provide to children with disabilities the same basic opportunities for a meaningful education as nondisabled children have. Opening the school doors so that the former have reasonable opportunities to learn, but not assuring them an opportunity to reach their maximum potential, was considered to be Congress' intent, nothing more. Rowley thus addressed the goal of an education, not just how that goal is to be reached (e.g., with or without an interpreter).

\section{The IEP}

Second, it is clear that another of Rowley's tenets is that individualized education programs, developed by a team of professionals and parents, are deemed to be appropriate. That proposition flies squarely in the face of legislative judgments, usually based on fiscal policy, that a school year should be limited to a fixed number of days a year. Although fiscally and politically defensible, that decision does not satisfy the Rowley demand for individualization of education, based on professional judgment.

\section{Year-Round Education}

It was therefore predictable that inflexible school year limits would be tested on behalf of children with disabilities. On 12-month education, the leading case is Armstrong v. Klein (1980). In that case, the federal district court held that the state's refusal to pay for more than 180 days of schooling each year for children who are severely and profoundly retarded and severely emotionally disturbed violated their rights to an appropriate educa- 
tion under the EHA. The court ruled that an appropriate education is one that allows the children to become self-sufficient within the limits of their disabilities, not just one that allows them to share equally in programs provided to nonhandicapped students or to reach one of several other goals. The court also noted that some children regress significantly during breaks in their education, recoup their losses more slowly than nonhandicapped children, and thus are denied an appropriate education when they are not given year-round education.

\section{Appropriate Education as Process}

Third, Rowley affirmed the process definition of appropriate education. Enroll the child, evaluate, do an IEP, and place him or her in the least restrictive environment. That certainly seems consistent with the scheme of the EHA. Of course it often begs the question of substance: Does the process yield a professionally acceptable result that parents also adopt?

\section{Related Services}

Fourth, Rowley came to the Court as an appropriate education case in the posture of the requirements for related services (an interpreter). Although the Court decided against the claim for an interpreter for the child, it did not argue with the proposition of the EHA that an appropriate education depends, in some cases, on the availability of related services. Indeed, the Court itself in Tatro has clarified one important aspect of related services. The general issue there was how to distinguish between a related service and a medical service. The specific issue was whether clean intermittent catheterization (CIC) is a related service (under Part B of the EHA) that a school must provide or a medical service that it is not required to provide except for diagnostic or evaluation purposes. Federal trial and appeals courts had held that CIC is a related service. The Supreme Court affirmed, holding in an unanimous opinion that CIC is a related service that schools must provide.

In Tatro, the Supreme Court found as a matter of fact that CIC is a "simple procedure
... that may be performed in a few minutes by a layperson with less than an hour's training." Indeed, the student herself soon would be able to perform the service, as her parents, babysitters, and teenage brother had been doing all along.

The Court was faced with the legal issue whether CIC is a related service under the EHA (Sec. 1401[7]). To decide that, it had to determine whether CIC is a "supportive service" required to "assist a handicapped child to benefit from special education" and, next, whether CIC is excluded from the supportive service definition because it is a medical service serving purposes other than diagnosis or evaluation.

The Court held that CIC is a related service because, without it, the student could not attend school and thereby benefit from special education. Congress' intent, said the Court (relying on its earlier decision in Rowley), was to make a public education available and to make access to school meaningful. A service that makes it possible for the child to "remain at school during the day is an important means of providing the child with the meaningful access to education that Congress envisioned." It is clear that the Court was not about to allow any violation of the zero-reject principle by permitting schools to escape the obligation of this type of related service. It also is apparent that the Court was concerned that children have an opportunity for meaningful access. Its concern with prohibiting functional exclusion is apparent, too. And the Court may have been concerned with exclusion of the student from education with nondisabled students, although it did not refer to the LRE principle.

Next, the Court found that CIC is not a medical service that the school must provide for diagnosis or evaluation. There are two reasons for this conclusion. First, the Court deferred to the Department of Education regulations, which ruled CIC to be a related, not a medical, service. Second, the Court found that Congress plainly required schools to hire various specially trained personnel and that school nurses have long been a part of educational systems. It also noted that nurses have authority to dispense oral medication and to administer emergency injections and that it is difficult to distinguish CIC from these services. 


\section{Psychotherapy as a Related Service}

How far should the related services requirement extend? Specifically, does the related services requirement apply to psychotherapy? Several of the dispositive facts in Tatro and its holding that CIC is a related service are not present in cases involving psychotherapy. For example, trained laypersons can perform CIC. Indeed, CIC can be self-administered. By contrast, psychotherapy can be performed lawfully and competently (it is presumed) only by licensed physicians with special training and qualification in psychiatry. Rarely it is self-administered in the Tatro sense of the patient and professional being one and the same person.

In addition, the cost of CIC is relatively low, and its benefits to the child (enhanced opportunity for life and for education, particularly with nondisabled children) are great. The cost-benefit ratio favors CIC and disfavors schools' objections to providing it. On the other hand, the cost-benefit ratio does not favor psychotherapy as a related service that school districts must either pay for (so others can provide it) or provide themselves.

In The Matter of the " $A$ " Family (1979) is a state court decision holding that out-ofstate placement in a private residential facility for seriously emotionally disturbed children, at which the child would receive psychotherapy, is placement in the least restrictive alternative for the child, and that costs of the tuition and the therapy must be paid by a local school district under the EHA's provision for related services. Psychotherapy is a related service, not a medical service, because it is a "treatment of mental or emotional disorders or of related bodily ills by psychological means,"' according to Webster's New Collegiate Dictionary. It thus comes within the definition of psychological services.

Other cases also tend to be expansive and liberal about psychotherapy, usually in the context of residential hospitalization (as contrasted with school-based special education and psychotherapy as a related service). Thus Gladys J. v. Pearland Independent School District (1981) and Kruelle v. New Castle County School District (1981) both held that an appropriate education for severely emotionally disturbed children includes psychotherapy and 24-hour, 12-month residential placement. Other cases concur in this result, holding that school nurses' and physicians' charges at a residential facility should be paid by the school district that placed the child there since the physicians' charges are for evaluations and diagnostic and prescriptive services, not treatment.

Similarly, in Gary B. v. Cronin (1982), the plaintiffs were emotionally disturbed children challenging a state rule that excludes counseling and therapeutic services from special education services. The court issued a preliminary injunction preventing implementation of the rule that would deny money for counseling and therapy and a free appropriate education to the plaintiff.

By contrast, McKenzie v. Jefferson (1983) held that the residential component of a psychiatric hospital placement is medical, not educational, in nature and is not to be paid for by a school district, because it is not a related service. A concurring case is Darlene L. v. Illinois State Board of Education (1983).

\section{SUMMARY}

In my judgment, the Supreme Court's Tatro decision was correctly decided and its principles are sound, with regard to the behavior and functions of schools and with regard to both values and principles. The same is true, I believe, of the 12-month school year cases and Rowley. These cases build on the process definition, although with too much reliance in the language of the Court in Rowley on school-based professionals' opinion (perhaps justified in that case in light of the student's academic progress). They keep the IEP as the focal point of appropriateness. They adhere to the comparability standard, although with great effort in the 12-month school year and psychotherapy cases. They recognize the necessity of related services for appropriateness. And they emphasize the child's right to and need for an appropriate (beneficial) education. In these respects schools' behaviors and functions are properly required to be child-centered and appropriately individualized.

But these cases also seem correct because they adopt the correct (integrative) values and principles of education (both regular and special). All of these cases seem to emphasize the need for integration of students who have disabilities with students who do NOT. Tatro required catheterization so that the student 
could continue her education at school (instead of home). The 12-month school year cases seem to say that the extended school year is required so some children can continue to receive educational services at all; in the absence of summer schooling, they may regress so much that it would be pointless to require schools to educate them at all. And Rowley made much of the fact that the student was integrated with nondisabled students and passing from grade to grade.

In these cases, the principle that schools must provide certain services is associated with the value of integration. The cases thus require a relatively new behavior of schools -appropriate education (i.e., the opposite of functional exclusion). And the cases also require a relatively new function of schools-to take on some of the responsibilities of other agencies. The value is integration. The objective is to prevent exclusion.

Just how far the courts will pursue these behavior-shaping and function-changing principles and values remains to be seen. The decisive test may be the psychotherapy cases. There, the courts may take into account the costs of school-provided therapy, the drastic change of role from providing education to practicing medicine, the length of time required for successful intervention, the professional qualifications required of the provider, and the comparability requirements of the EHA (as interpreted in Rowley and as seen under the "reasonable accommodations" test of Southeastern Community College v. Davis [1979]).

In considering any one of these factors, and especially in considering a combination of them, the courts may decide that the integration principle should yield to considerations of cost, time, and professionalism and should be modified because the child could receive more effective individualized services in other service systems. In this event, the child arguably would not be denied an appropriate education (since the psychiatric and possibly educational services would still be provided by other agencies) but would receive them in a less integrated setting (e.g., in a psychiatric hospital).

Indeed, that result-exclusion from schoolbased services and inclusion in other service providers' systems for receipt of special education and related services-is a major issue of the EHA's requirements for least restrictive alternatives or environments (LRA/LRE).

To the extent (which is not sufficient) that courts use the LRA principle and other EHA provisions to create new programs of appropriate education within the schools, the appropriate education rule (individualization) and the appropriate education value (integration) advance each other and continue to attack vestiges of a dual system of education. To the extent (which is too frequent), however, that courts simply choose between one program and another (e.g., school-based or institution-based), they abjure appropriateness and integration as a combined goal and adhere only to appropriateness as a single goal. There is enough in Rowley, Tatro, and the 12-month schoolyear cases-enough about the value of integration-to make strong arguments for the combined approach (appropriateness and integration). In the end, that approach, indirectly advanced in Rowley, may be Rowley's greatest contribution.

\section{REFERENCES}

Armstrong v. Klein, 513 F. Supp. 425, 629 F.2d 269 (3d Cir. 1980).

Board v. Rowley, 458 U.S. 176, 102 S. Ct. 3034, 73 L.Ed. 2d 690 (U.S.S.CT. 1982).

Darlene L. v. Illinois State Board of Education, EHLR 554:532 (N.D. Ill. 1983).

Education of the Handicapped Act, 20 U.S.C. Secs. 1401-1461.

Gary B. v. Cronin, 542 F. Supp. 120 (N.D. Ill. 1982).

Gladys J. v. Pearland Independent School District, 520 F. Supp. 869 (S.D. Tex. 1981).

In The Matter of the " $A$ " Family, 602 P. 2d 1257, EHLR 551:345 (S. Ct. Mont., 1979).

Irving I.S.D. v. Tatro, 104 S. Ct. 3371, 82 L.Ed. 2d 664 (1984).

Kruelle v. New Castle County School District, 489 F. Supp. 169, 642, F. 2d 687 (3d. Cir. 1981).

McKenzie v. Jefferson, EHLR 554:438 (D.D.C. 1983).

Mills v. D.C. Board of Education, 348 F. Supp. 366 (D.D.C. 1972).

Pennsylvania Association for Retarded Children v. Commonwealth of Pennsylvania, 334 F. Supp. 1257, 343 F. Supp. 279 (E.D. Pa. 1971, 1972).

Southeastern Community College v. Davis, 442 U.S. 397 (1979).

This article is adapted and excerpted from Turnbull, H. R., Free Appropriate Public Education: Law and Interpretation (1986), with permission of the author and of the publisher, Love Publishing Company, Denver, Colorado. 